\title{
Exposure to ticks and undertaking Lyme borreliosis prevention activities among students from Poland and Slovakia
}

\author{
Anna Pańczuk ${ }^{1, B-F}{ }^{\oplus}$, Małgorzata Tokarska-Rodak ${ }^{1, A-B, E-F \oplus}$, Wioletta Mikuláková2,B,F®,

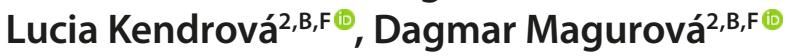 \\ 1 Pope John Paul II State School of Higher Education, Biała Podlaska, Poland \\ 2 Presov University, Slovakia \\ A - Research concept and design, B - Collection and/or assembly of data, C - Data analysis and interpretation, \\ $D$ - Writing the article, E-Critical revision of the article, F- Final approval of article
}

Pańczuk A, Tokarska-Rodak M, Mikuláková W, Kendrová L, Magurová D. Exposure to ticks and undertaking Lyme borreliosis prevention activities among students from Poland and Slovakia. Ann Agric Environ Med. 2019; 26(2): 217-221. doi: 10.26444/aaem/99089

\begin{abstract}
Introduction and objective. The incidence of Lyme borreliosis (LB) is increasing in many countries in Europe, including Poland and Slovakia. The aim of the study was to analyze the exposure to tick bites and undertaking LB prevention activities among students of medical fields of studies in Poland (PL) and Slovakia (SK).

Materials and method. The study was conducted among 611 students from Poland (296 students) and Slovakia (315 students). The applied research tool was the questionnaire. It consisted of questions about exposure to ticks (occurrence of an episode of tick bites, bite site, methods used for tick removal) and the frequency of undertaking preventive actions (using repellents, checking the body after returning from green areas). Pearson Chi-square statistics were calculated to assess significant differences between students from the study countries PL/SK and gender in each country.

Results. Among surveyed students the episode of a tick bite was reported by 352 persons (57.6\%). Students from PL most frequently removed ticks with tweezers with a swift, steady movement (26.6\%), while students from SK removed the tick by applying a fatty substance so that it would come off by itself (30.1\%). Most of the surveyed students, being outdoors, did not apply ticks repellents (34.7\%) or used them rarely (48.9\%). At the same time, $49.4 \%$ of students stated that they always checked the body to search for any attached tick after returning from green areas.

Conclusions. Considering the fact that the surveyed people were the students of medical fields of studies, and in the future became qualified medical personnel, the frequency of using the analyzed methods of prophylaxis of LB appears to be too small. The results obtained can help in the education of students of medical fields.
\end{abstract}

\section{Key words}

Poland, Slovakia, students, Lyme borreliosis, ticks bites, preventive behaviours

\section{INTRODUCTION}

Lyme borreliosis (LB) is the most common tick-borne infection in countries with moderate climates in Eurasia and in North America and represent a serious problem for general public health. The disease is caused by spirochaetes of the Borrelia burgdorferi sensu lato species complex, which are transmitted by specific Ixodes spp. ticks [1]. The main vector of LB in Europe is Ixodes ricinus. The distribution area of $I$. ricinus has significantly expanded in recent decades. Tick vectors have increased in abundance, habitat expanded, including urbanized areas, and prolonged the questing activity periods [2].

Surveillance in Europe varies and does not allow direct comparison between countries. It appears that both LB incidence and antibody against $B$. burgdorferi s.l. prevalence are higher in the central and eastern parts of Europe than in the western parts. In many countries in Europe, the number of reported cases of LB has increased since the early 1990s, and the geographic distribution of cases has also expanded [3]. In Poland, the increased trend in the number of cases

Address for correspondence: Anna Pańczuk, Pope John Paul II State School of Higher Education in Biała Podlaska, ul. Sidorska 95/97, 21-500 Biała Podlaska, Poland e-mail: anna.panczuk@poczta.onet.pl

Received: 29.06.2018; accepted: 20.10.2018; first published: 30.11 .2018 of LB is observed from the beginning of registration of the disease, that is, from the $2^{\text {nd }}$ half of the 1990s. In 2016, there were 21,200 cases of LB registered in Poland and the incidence was 55.2 per 100,000 population [4]. Slovakia, a neighbouring country, recorded lower rates of incidence of LB in comparison to Poland. The number of registered cases of LB in Slovakia in 2016 amounted to 1,105 cases (incidence 20.36 / 100,000) [5].

There is a need to strengthen preventive measures against $\mathrm{LB}$, such as disseminating information to the general public [3]. The lack of an effective vaccine implies that at present the best method of personal prevention of LB are: avoiding areas with a high density of ticks, wearing protective clothes, application of tick repellents, checking the body after being in a risk environment, proper removal of ticks, and in the case of tick bite, regular examination of the bite site during the following weeks in order to initiate an early curative treatment if erythema migrans is diagnosed $[6,7]$.

\section{OBJECTIVE}

The aim of the study was to analyze the exposure to tick bites and undertaking Lyme borreliosis prevention activities among students of medical fields of studies from the neighbouring countries Poland and Slovakia. 


\section{MATERIALS AND METHOD}

Study design. The study was conducted in 2015 among 611 students of medical fields of studies from Poland (296 students of the State School of Higher Education in Biała Podlaska, eastern Poland) and Slovakia (315 students of the University in Presov, eastern Slovakia). Among the Polish students $64.9 \%$ were nursing students (192 persons), and $35.1 \%$ were students of emergency medical services (104 persons). In the group of students from Slovakia, those studying nursing also prevailed $-74.9 \%$ (236 persons). Students of emergency medical services accounted for $25.1 \%$ (79 persons). Among students from Poland, as well as from Slovakia, women were the majority, who accounted for $65.7 \%$ and $79.2 \%$, respectively. The average age of students from Poland was 23.3 years $(\mathrm{SD}=4.36)$, and from Slovakia 22.2 $(\mathrm{SD}=2.26)$.

Study instrument. The applied research tool was the author's questionnaire. It consisted of questions about exposure to ticks (occurrence of tick bite episodes in the whole life of respondents, bite sites, methods used for tick removal) and the frequency of undertaking preventive actions (using repellents, checking the body after returning from green areas). In questions about bite sites and methods used for tick removal, the respondents could choose more than one answer. In addition to the above questions, the questionnaire contained demographics, including information on age, gender, field and year of study.

Data analysis. Responses of the surveyed students from PL and SK were subjected to statistical analysis. Analysis was also performed with regard to gender in different countries (PL: men/women, SK: men/women). In order to test the hypotheses about the independence of the characteristics, the Pearson's chi-squared test $\left(\chi^{2}\right)$ was used. In one case, at the sample size below 5, the Yates' correction formula $\left(\chi_{y}^{2}\right)$ was applied. In statistical inference, the level of significance was at 0.05. Statistical analyses were performed with STATISTICA software v. 10.0 (StatSoft, Poland).

\section{RESULTS}

Among the 611 surveyed students an episode of a tick bite was reported by 352 persons (57.6\%). Tick bites were significantly more often reported by students from SK (67.6\%) than from PL $(47.0 \% ; \mathrm{p}<0.001)$. In the group of students bitten by ticks, multiple bites were reported by $49.7 \%$. Also in this case, students from SK significantly more often reported multiple bites than students from Poland (SK: 58.7\%; PL: $36.0 \%$; $<0.001)$. Both in PL and SK tick bites were more often declared by men (PL: 50.0\%/44.2\%; SK: 75.4\%/65.7\%); however, these differences were not statistically significant.

The most frequently reported areas of tick bites were the lower limbs (46.0\%), abdomen (33.2\%) and upper limbs (30.7\%). Students from SK significantly more often than students from PL reported bites on the lower and upper limbs (Tab. 1).

Students from Poland usually removed the ticks by tweezers with a swift, steady movement (26.6\%) or by twisting (18.7\%). Students from Poland also significantly more often declared using the help of qualified medical personnel (physician or nurse) (27.3\%). Students from Slovakia more often removed the tick by applying a fatty substance so that it would come off by itself (30.1\%); this method was used significantly more often than in the group of students from Poland $(0.7 \%$; $\mathrm{p}<0.001)$. They declared significantly more often pouring disinfectant on to the attached tick (8.0\%), scratching it off with a fingernail (7.5\%) and disinfecting the skin area after removal of the tick (31.9\%) (Tab. 1).

Table 1. Sites of tick bite and methods of tick removal used among bitten students in Poland and Slovakia

\begin{tabular}{|c|c|c|c|c|c|c|c|c|}
\hline & & \multicolumn{2}{|c|}{$\begin{array}{c}\text { Total } \\
(\mathrm{N}=352)\end{array}$} & \multicolumn{2}{|c|}{$\begin{array}{l}\text { Poland } \\
(\mathrm{N}=139)\end{array}$} & \multicolumn{2}{|c|}{$\begin{array}{l}\text { Slovakia } \\
(\mathrm{N}=213)\end{array}$} & \multirow[t]{2}{*}{$\mathrm{p}$} \\
\hline & & $\mathrm{n}$ & $\%$ & $\mathrm{~N}$ & $\%$ & $\mathrm{n}$ & $\%$ & \\
\hline \multirow{7}{*}{ Site of bite* } & lower limb & 162 & 46.0 & 50 & 36.0 & 112 & 52.6 & 0.002 \\
\hline & neck & 61 & 17.3 & 24 & 17.3 & 37 & 17.4 & 0.980 \\
\hline & chest & 33 & 9.4 & 8 & 5.8 & 25 & 11.7 & 0.060 \\
\hline & back & 61 & 17.3 & 18 & 13.0 & 43 & 20.2 & 0.079 \\
\hline & head & 62 & 17.6 & 20 & 14.4 & 42 & 19.7 & 0.199 \\
\hline & abdomen & 117 & 33.2 & 42 & 30.2 & 75 & 35.2 & 0.331 \\
\hline & other & 22 & 6.3 & 13 & 9.4 & 9 & 4.2 & 0.052 \\
\hline \multirow{10}{*}{ Methods of tick removal* } & grasped in fingers and pulled out & 39 & 11.1 & 11 & 7.9 & 28 & 13.2 & 0.126 \\
\hline & removed with tweezers with a swift, steady movement & 78 & 22.2 & 37 & 26.6 & 41 & 19.3 & 0.104 \\
\hline & twisted out with tweezers & 53 & 15.1 & 26 & 18.7 & 27 & 12.7 & 0.122 \\
\hline & scratched off with a fingernail & 18 & 5.1 & 2 & 1.4 & 16 & 7.5 & 0.012 \\
\hline & poured disinfectant on the tick with & 21 & 6.0 & 4 & 2.9 & 17 & 8.0 & 0.048 \\
\hline & applied fatty substance on the tick & 65 & 18.5 & 1 & 0.7 & 64 & 30.1 & $<0.001$ \\
\hline & disinfection of the site after removing the tick & 94 & 26.7 & 26 & 18.7 & 68 & 31.9 & 0.006 \\
\hline & removed by physician or nurse & 76 & 21.6 & 38 & 27.3 & 38 & 17.8 & 0.034 \\
\hline & removed by other person & 185 & 52.6 & 51 & 36.7 & 134 & 62.9 & $<0.001$ \\
\hline & other methods & 11 & 3.1 & 4 & 2.9 & 7 & 3.3 & 0.829 \\
\hline
\end{tabular}

* results do not add up to $100 \%$ due to the possibility of multiple choice of reply 
Both in Poland and Slovakia, significantly more men than women removed the ticks with tweezers with a swift, steady movement (PL: 34.7\%/19.3\%; $\mathrm{p}=0.048$. SK: 30.6\%/16,6\%; $\mathrm{p}=0.031$, whereas women significantly more often disinfected the site after removing the tick (PL: $6.1 \% / 24.1 \%$; $=0.017$. SK: $10.2 \% / 38.0 \% ; \mathrm{p}<0.001)$. Among the students from Slovakia, men significantly more often scratched the ticks off with a fingernail $(18.4 \% / 4.3 \%$; $p=0.001)$, whereas women more often applied a fatty substance to the tick so that it would come off by itself $(16.3 \% / 34,4 \%$; $\mathrm{p}=0.016)$. On the other hand, in Poland, women often benefitted from the help of others when removing ticks $(20.4 \% / 45.8 \% ; \mathrm{p}=0.003)$.

Most of the surveyed students, being outdoors, did not apply ticks repellents (34.7\%) or used them rarely (48.9\%). Only $16.4 \%$ of students stated that they always used this form of prevention. The use of repellents was more often declared by students from Slovakia than students from Poland; however, the differences proved to be statistically insignificant (Fig. 1). Analysis by gender among students from Slovakia did not show statistically significant differences, while among students from Poland, repellents were used significantly more often among women $(\mathrm{p}<0.001)$.

Nearly half of all surveyed students (49.4\%) declared that after returning from green areas they always checked the body to search for any attached ticks. Other students, however, did not adhere to this principle (11.5\%) or used it rarely (39.1\%). No significant differences were found in the declared frequency of this form of prophylaxis of tick-borne diseases between students from both analysed countries (Fig. 1). Analysis by gender revealed that among Polish students, significantly more often this principle was applied by females $(\mathrm{p}=0.003)$.

\section{DISCUSSION}

The distribution area of I. ricinus has significantly expanded in Europe. I. ricinus is primarily associated with shrubs and deciduous and mixed forests. However, as a consequence of changing land use and wildlife management, tick populations have also been observed in urban and peri-urban sites in many European countries [2].

Among the surveyed students, episodes of tick bite were declared by more than half of the respondents (57.6\%). On the basis of the results obtained, differences were observed in exposure to ticks between the students from Poland and Slovakia. Significantly more often the tick bite was reported by students from Slovakia (67.6\%). An episode of tick bite among Polish students was declared by $47.0 \%$. The results obtained among students from Poland are lower than in previous studies. In the study conducted at the same University among students of the tourism and recreation faculty, episodes of tick bite were declared by $55.4 \%$ [8], and in research among young people from this region of Poland $-58.9 \%$ [9]. In the study in eastern Slovakia, a history of the tick bite was reported in $37.3 \%$ of healthy blood donors [10] and in $87.0 \%$ of persons exposed to tick bite [11].

In the studies, the most often declared sites of tick bites among adults were the limbs, especially the lower limbs $[12,13,14,15,16,17]$. Among the surveyed students, the most frequently reported sites of tick bites were also the lower limbs (46.0\%). In studies of the youth, most were also bitten by ticks on the lower limbs (59.4\%) [17]. In studies of patients who reported to health facilities in the province of Lublin in eastern Poland due to bites by ticks, the most common sites of the tick bites were the upper (28.8\%) and lower (27.1\%) limbs [18].

The lack of an effective vaccine against LB implies that at present the best method of personal prevention. An important element in the prophylaxis of $\mathrm{LB}$ is to remove correctly a feeding tick as soon as possible, because the longer the infected tick feeds, the greater the risk of possible infection of the spirochetes of B. burgdorferi $[1,19,20,21]$. It is recommended to grasp the tick with tweezers as close to the skin as possible, and pull it with a simple, smooth and at the same time firm movement. After removing the tick, disinfect the skin [22]. Considering the fact that the surveyed people were the students of medical fields of studies, and future qualified medical personnel, the use of non-recommended methods of ticks removal is particularly worrying. On the basis of the results obtained, differences were observed in activities undertaken in relation to tick bites between students from Poland and Slovakia. The recommended method for removing ticks was the most frequently used among Polish students (26.6\%). In turn, the recommended disinfection of the site after removal of ticks was declared significantly more often by students from Slovakia (31.9\%) than from Poland. Among the students from both countries, women significantly more often remembered this.

Among the surveyed students there were used nonrecommended ways of ticks removal, which increases the risk of infection. It was particularly disturbing that among the students from Slovakia, it was found that a popular method of tick removal involved applying a fatty substance on the tick so that it would come off by itself. This was the most commonly used method of removing a tick in this group (30.1\%), especially among women. Ticks should never be covered with such substances as grease, petrol, kerosene, petroleum jelly or nail varnish, as the suffocating tick introduces pathogens into the skin along with its vomit [23], which facilitates the possible infection of B. burgdorferi. This method, together with pouring disinfectant on a tick and scratching it off with fingernail were used significantly more frequently among students from Slovakia, compared to students from Poland. Other studies also indicate a low level of knowledge about the correct way of tick removal. In the study of Polish students of the tourism and recreation faculty, $52.7 \%$ did not know how to correctly remove a tick attached to the skin, and the most frequently reported method of removal was twisting out with tweezers (28.0\%) [8]. This method also proved to be the most common in studies of young people from the north of the Lublin Region of eastern Poland (24.5\%) [9]. In other studies in the Lublin macroregion, the most common method of removing a tick was pulling it out with the fingers (44\%). Only $17 \%$ of respondents stated that they used the safest and recommended method for removing ticks with tweezers [24]. In a study of forestry workers occupationally exposed to tick bites nearly all of them believed that they removed ticks properly. However, although a half of the workers removed ticks with the use of tweezers or special hooks, a large proportion of them (43.6\%) removed the ticks improperly - with fingers [25].

Among two analyzed methods of prophylaxis of LB involving the use of repellents and checking the body after returning from the green areas, the most popular proved to be checking the body. Nearly half of all surveyed students 
(49.4\%) declared that they always check the body for the presence of a tick after returning from green areas. In the study of students of tourism and recreation, $16.9 \%$ of respondents stated that they always use this method, while $30.4 \%$ use it often [8]. In the study of students of the faculties of science from Poland and the Czech Republic, in the Czech group, checking their body for ticks after visiting a tickinfested area was the most common preventive measure. This method was significantly more often used within this group rather than among students from Poland. In a significantly higher number of cases, the Polish students preferred having a shower after being outdoors than the Czechs. Checking their body for ticks after visiting a tick-infested area was more often used by women (CZ: 89\% female/54\% male. PL: $17 \%$ female $/ 4 \%$ male) [26]. Also, in own research among students from Poland, this form of prophylaxis was used significantly more often among women. In the study among forestry workers, $65.1 \%$ of the workers always checked their body for the presence of ticks after returning from the forest, while $32.1 \%$ did so only sporadically [25].

Repellents are an effective measure for reducing the risk of tick bites and can therefore minimize the transmission of tick-borne diseases [6]. The use of repellents was declared by $65.3 \%$ of the surveyed students, compared to those who used them rarely (48.9\%). The use of repellents was more often declared by students from Slovakia; nevertheless, the differences proved to be statistically insignificant. Using this form of prophylaxis was even less popular among the students of tourism and recreation from Poland. The use of this method was declared by $40.5 \%$ of respondents, and within this group dominated people who used it rarely [8]. Similar results were obtained in studies of young people from the north of the Lublin Region. In this group, the use of repellents was declared by $42.6 \%$, but those who used them rarely also dominated [9]. In the study of students from Poland and Czech Republic, among the Polish respondents, the usage of repellents was the most common measure to prevent tick bites. In both countries, repellents were more often used by women (PL: 65\% female/33\% male. CZ: 64\% female $/ 50 \%$ male) [26]. Also, in own research, among students from Poland the repellents were more often used by women. In a study among forestry workers, the majority (51.8\%) always used repellents when working in the forest, but a large proportion of them (41.8\%) did so only sporadically [25]. Among individuals in southwestern Connecticut in the USA, the use of tick repellent was the least commonly reported method (38\%) [27]. The use of a repellent was also very rarely reported in a study from Finland (15\% of respondents claimed to use them sometimes, and 5\% always). This could be due to the negative attitude about repellents in general. Participants of the study did not believe the efficacy of tick repellents, and aligned with this, they hardly declared using them while visiting tick-infested places. Tradition and previous public health communication could be one of several reasons for the differences between countries [28].

\section{CONCLUSIONS}

Considering the fact that the surveyed people were students of medical fields of studies, the frequency of using the analyzed methods of prophylaxis of LB appears to be too little. It can be expected that the preventive behaviors and knowledge of LB among the general public are rather limited in comparison with the students participating in the study, who are educated in this field. The results obtained can assist in educating the students in various medical fields.

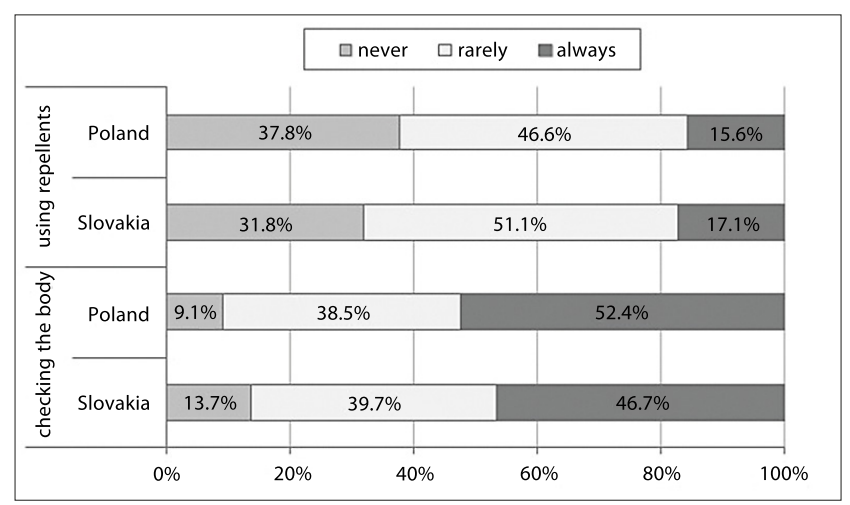

Figure 1. Frequency of using repellents and checking the body after returning from green areas among the surveyed students from Poland and Slovakia

\section{Conflict of interest}

The authors declare that they have no conflict interests.

\section{Funding sources}

This research did not receive any specific grant from funding agencies in the public, commercial, or not-for-profit sectors.

\section{Acknowledgements}

We would like to thank M. Wasilewska for providing language help and A. Szepeluk from Innovation Research Centre, Pope John Paul II State School of Higher Education in Biala Podlaska, for assistance with statistical analysis.

\section{REFERENCES}

1. Stanek G, Wormser GP, Gray J, Strle F. Lyme borreliosis. Lancet. 2012; 379(9814): 461-473.

2. Rizzoli A, Silaghi C, Obiegala A, Rudolf I, Hubálek Z, Földvári G, et al. Ixodes ricinus and Its Transmitted Pathogens in Urban and Peri-Urban Areas in Europe: New Hazards and Relevance for Public Health. Front Public Health. 2014; 2: 251.

3. Lindgren E, Jaenson TGT. Lyme borreliosis in Europe: influence of climate and climate change, epidemiology, ecology and adaptation measures. WHO, Regional Office for Europe, 2006.

4. National Institute of Public Health - National Institute of Hygiene. Infectious diseases and poisonings in Poland in 2016. Warsaw. http:// wwwold.pzh.gov.pl/oldpage/epimeld/2015/Ch_2015.pdf (access: 2017.06.24)

5. Epidemiological Information System. Analýza epidemiologickej situácie a činnosti odborov epidemiológie v Slovenskej republike for 2016. http://www.epis.sk/InformacnaCast/Publikacie/VyrocneSpravy. aspx (access: 2017.06.24).

6. Cisak E, Wójcik-Fatla A, Zając V, Dutkiewicz J. Repellents and acaricides as personal protection measures in the prevention of tickborne diseases. Ann Agric Environ Med. 2012; 19(4): 625-630.

7. Clark RP, Hu LT. Prevention of Lyme Disease (and other tick-borne infections). Infect Dis Clin North Am. 2008; 22(3): 381-396.

8. Pańczuk A, Kozioł-Montewka M, Tokarska-Rodak M. Wiedza na temat boreliozy oraz podejmowanie działań profilaktycznych wśród studentów Państwowej Szkoły Wyższej w Białej Podlaskiej In: TokarskaRodak M, Markert R, editors. Społeczne, środowiskowe i biologiczne zagrożenia zdrowia a kształtowanie zachowań prozdrowotnych, Biała Podlaska; 2014. p. 155-165.

9. Pańczuk A, Kozioł-Montewka M. Exposure to ticks and preventive actions in the scope of Lyme disease among young people from the northern part of Lublin province (eastern Poland). Health Problems of Civilization. 2017; 11(1): 48-55. 
10. Zákutná L, Dorko E, Rimárová K, Kizeková M. Pilot Cross-Sectiona Study Of Three Zoonoses (Lyme Disease, Tularaemia, Leptospirosis) Among Healthy Blood Donors In Eastern Slovakia. Cent Eur J Public Health. 2015; 23(2): 100-106.

11. Zákutná L, Dorko E, Mattová E, Rimárová K. Sero-epidemiological study of Lyme disease among high-risk population groups in eastern Slovakia. Ann Agric Environ Med. 2015; 22(4): 632-636.

12. Hügli D, Moret J, Rais O, Moosmann Y, Erard P, Malinverni R, et al. Tick bites in a Lyme borreliosis highly endemic area in Switzerland. Int J Med Microbiol. 2009; 299(2): 155-160.

13. Wilhelmsson P, Lindblom P, Fryland L, Nyman D, Jaenson TGT, Forsberg P, et al. Ixodes ricinus ticks removed from humans in Northern Europe: seasonal pattern of infestation, attachment sites and duration of feeding. Parasit Vectors. 2013; 6: 362.

14. Wierzbicka A, Raczka G, Skorupski M, Michalik J, Lane RS. Human behaviors elevating the risk of exposure to Ixodes ricinus larvae and nymphs in two types of lowland coniferous forests in west-central Poland. Ticks Tick Borne Dis. 2016; 7(6): 1180-1185.

15. Trombert-Paolantoni S, Ferquel E, Postic D. Retrospective study of Lyme borreliosis positive serologies in 2003. Pathol Biol (Paris). 2005; 53(8-9): 522-526

16. Aydin MF, Kocaman H. Evaluation of tick bites according to anatomical regions on humans in the light of the studies in Turkey. Balikesir Health Sciences Journal. 2015; 4(2): 122-124.

17. Pańczuk A, Kozioł-Montewka M, Tokarska-Rodak M. Exposure to ticks and seroprevalence of Borrelia burgdorferi among a healthy young population living in the area of southern Podlasie, Poland. Ann Agric Environ Med. 2014; 21(3): 512-517.
18. Bartosik K, Sitarz M, Szymańska J, Buczek A. Tick bites on humans in the agricultural and recreational areas in south-eastern Poland. Ann Agric Environ Med. 2011; 18(1): 151-157.

19. Zajkowska J. Lyme borreliosis-guidelines of treatment and expectations of patients. Przegl Epidemiol. 2008; 62(supl.): 142-151.

20. Steere AC, Coburn J, Glickstein L. The emergence of Lyme disease. J Clin Invest. 2004; 113(8): 1093-1101.

21. Rizzoli A, Hauffe HC, Carpi G, Vourc'h GI, Neteler M, Rosŕ R. Lyme borreliosis in Europe. Euro Surveill. 2011; 16(27): 2-9.

22. Stafford KC. Tick management handbook (bulletin No 1010). The Connecticut Agricultural Experiment Station, South Windsor, 2007. http://www.ct.gov/caes/lib/caes/documents/publications/bulletins/ b1010.pdf (access: 2016.09.10).

23. Tylewska-Wierzbanowska S, Chmielewski T. Tick-borne bacterial diseases in Poland. Health Problems of Civilization. 2017; 11(2): 56-65.

24. Bartosik K, Kubrak T, Olszewski T, Jung M, Buczek A. Prevention of tick bites and protection against tick-borne diseases in south-eastern Poland. Ann Agric Environ Med. 2008; 15(2): 181-185.

25. Cisak E, Zając V, Wójcik-Fatla A, Dutkiewicz J. Risk of tick-borne diseases in various categories of employment among forestry workers in eastern Poland. Ann Agric Environ Med. 2012; 19(3): 469-474.

26. Nejezchlebova H, Kiewra D, Žákovská A, Ovesná P. Students' attitudes to tick risks. Ann Agric Environ Med. 2016; 23(3): 437-441.

27. Butler AD, Sedghi T, Petrini JR, Ahmadi R. Tick-borne disease preventive practices and perceptions in an endemic area. Ticks TickBorne Dis. 2016; 7(2): 331-337.

28. Zöldi V, Turunen T, Lyytikäinen O, Sane J. Knowledge, attitudes, and practices regarding ticks and tick-borne diseases, Finland. Ticks TickBorne Dis. 2017; 8(6): 872-877. 